\title{
4.8 Реалізації інноваційних освітніх процесів у рамках організаційно- педагогічної співпраці школи та університету
}

Сьогодні зрозуміло, що зміна століть і тисячоліть веде до неминучих змін у суспільному житті. Перехід до посттехнологічного етапу суспільного розвитку, що супроводжується стрімким поширенням інформаційних технологій у всіх сферах життя, вимагає переосмислення існуючих освітніх підходів та пошуку нових.

У зв'язку з цим необхідно створити якісно нову освітню систему, здатну проектувати і відтворювати в реальності весь спектр явищ і зв'язків у матеріальному і духовному житті суспільства.

Виховні цілі відповідають історично та соціально відмінним ідеалам особистості та освіченої людини. Соціальні цілі та цілі учнів також взаємопов'язані: чим нижчий рівень освіти молодої людини, тим більше ії спонтанні цілі відхиляються від соціально-виховних. Розв'язання цього протиріччя передбачає поступове зближення, а в кінцевому підсумку - зближення особистісних смислів тих, хто займається освітою. У цьому контексті особливий інтерес і важливість представляє аналіз тих тенденцій, які виникли в минулому столітті і можуть тривати в сучасному, оскільки вони мають значний вплив на формування системи освіти.

Розгляд структури, типології і змісту інноваційного педагогічного процесу передбачає використання ідей загальної методології педагогічних нововведень і педагогічних інновацій, що були в центрі уваги таких науковців, як $\mathrm{P}$. Арцишевського, В. Безпалько, В. Бондар, С. Гончаренко, В. Гузеєва, I. Дичківськоъ, О. Дубасенюка, М. Ларіна, І. Козловськоъ, І. Мельничук, Л. Ребухи, Т. Назарова, Г. Селевко та ін.

На думку провідних експертів 3 питань освіти Ради Європи [324], зусилля світового співтовариства спрямовані на вирішення таких протиріч: 
- між загальним i особливим: поступове перетворення людини на громадянина світу, не втрачаючи свого коріння та $з$ активною участю в житті нації та її регіональних спільнот;

- між традицією та сучасністю: адаптація без заперечення свого коріння, діалектичний зв’язок між незалежністю та свободою, управління технічним прогресом, пов’язаним із розвитком нових технологій у сфері інформації;

- між істотним збільшенням інформації та здатністю людини іiі засвоювати;

- між змаганням за успіх і прагненням до рівних можливостей в економічній, соціальній та освітній політиці;

- між ринковою економікою та соціально орієнтованим ринковим суспільством.

Крім того, до ключових елементів навчання слід віднести три керівні освітні принципи: навчання здобувати знання; працездатність; навчитися жити.

Поняття «інновація» вперше з'явилося в дослідженнях культурології в 19 столітті і означало інтеграцію одних елементів однієї культури в іншу. На початку 20 століття сформувалася нова галузь знань - наука про інновації, в рамках якої вивчалися закономірності технічних нововведень у сфері матеріального виробництва.

Інноватика розвивалися як міждисциплінарна галузь досліджень на стику філософії, психології, соціології, теорії управління, економіки та культурології. Розвиток педагогічної інноватики в нашій країні пов’ язаний із масовим суспільнопедагогічним рухом, з виникненням протиріччя між наявною потребою швидкого розвитку школи та неспроможністю вчителів іiі реалізувати. У зв'язку з цим потреба в нових знаннях, в осмисленні нових понять «нове», «інновація», «інноваційний процес» тощо, постала більш гостро.

У педагогічній інноватиці дослідники, коли трактують поняття «інновація», у багатьох випадках йдуть за його розумінням у загальній інноватиці. Наприклад, А. Ніколлс у монографії «Управління педагогічними інноваціями» визначає інновацію як ідею, мету або практичну діяльність, що сприймається індивідом як дещо нове. У його розумінні інновація в освіті - 
це процес, що має життєвий цикл від зародження ідеї і створення нововведень до їі широкого розповсюдження в галузі освіти [325, с. 24].

Більшість дослідників визначають інноваційні процеси в освіті як систему, яка, активно відповідаючи на виклики соціокультурної дійсності та не відкидаючи існуючих традицій, вносить докорінні зміни в освіту, виховання та розвиток особистості.

В інноваційних процесах здійснюється трансформація не тільки самої педагогічної діяльності, притаманних ій ресурсів i механізмів, а й суттєво перебудовуються цільові установки та ціннісні орієнтації. Громадське сприйняття інноваційних ідей в освіті може бути досягнуто за умови забезпечення педагогічної взаємодії всіх суб’єктів освітнього процесу.

Одним із аспектів педагогічної взаємодії $\epsilon$ інноваційний навчальновиховний процес.

Інноваційні процеси передбачають відкритість до культури та суспільства, а також відкритість до свого «Я», власного внутрішнього світу. Педагогічне середовище організовано таким чином, щоб сприяти формуванню i розвитку образу «Я». В умовах інноваційної освіти створюються умови для розвитку особистості, використовується іï право на власний творчий внесок, за власною ініціативою, у свободу саморозвитку.

Інноваційні освітні процеси грунтуються на різних формах взаємодії, що розвиваються в логікі перебудови рівнів саморегуляції - від максимальної допомоги вчителя дітям у вирішенні виховних завдань до послідовного підвищення їхньої власної активності до повноцінної саморегуляції об’єктної діяльності. дії та виникнення партнерської позиції з учителем (В.Я. Ляудис) [326].

Розуміння педагогічних інновацій вимагає розгляду понять «інтеграція» та «педагогічна інтеграція», оскільки в сучасній педагогічній літературі існує неоднозначне тлумачення. Так, у тлумачному словнику української мови інтеграція (лат. integer — один, ціле) позначається як «об’єднання чогось в одне» [327]. Науковці І. Козловська, Л. Загорулько розглядають поняття «інтеграція» як колективне взаємопроникнення компонентів/елементів одного об'єкта в 
структуру іншого. Результатом цього процесу є вдосконалення певних якостей цих об’єктів, які постали як абсолютно новий об'єкт зі своїми властивостями [328]. Поняття «інтеграція» нероздільне iз словосполученням «педагогічна інтеграція», що тлумачиться як форма прояву єдності мети, принципів, змісту, форм організації процесу навчання i виховання [327]. Педагогічна інтеграція як різновид наукової інтеграції, здійснюється в межах педагогічної теорії i практики. Основою інтеграції педагогічних технологій, на переконання О. Мариновської, слугує побудова освітнього процесу на засадах виявлення в різних навчальних дисциплінах подібних елементів i поєднання їx $\mathrm{y}$ якісно нову цілісність для результативного формування життєво-важливого професійного образу майбутнього фахівця[329]. Наслідком такого об’єднання є інтегративна інноваційнопедагогічна технологія.

Цілісне розуміння інноваційних процесів вимагає розкриття провідних тенденцій і протиріч їх розвитку. Інноваційні процеси, що поєднують створення, розвиток та застосування педагогічних інновацій, завдяки своїй єдності можуть значно прискорити процеси оновлення системи освіти в цілому. I тому вивчення та впровадження всіх трьох ланок інноваційних процесів не випадкові; вони все більше інтегруються в систему освіти на різних рівнях, аж до окремих шкіл.

Одним із важливих завдань сучасної педагогічної інноватики є класифікація інновацій, знання якої необхідно вчителю, щоб зрозуміти особливості педагогічних інновацій, зрозуміти, що їх об’єднує та відрізняє одне від одного. Зазвичай вважають, що закони виражаються пропорціями, а класифікація та їх особливий випадок — типологія — лише передують відкриттю законів [330]. Сучасні дослідження наукової методології показують, що класифікації - це також закони науки, тільки іншого типу.

У навчальній літературі виділяють два типи інноваційних процесів в освіті. Перший тип - це інновації, що виникають переважно спонтанно, без точного відношення до самої генеративної потреби або без повного усвідомлення всієї 
системи умов, ресурсів і способів реалізації інноваційного процесу. Такі інновації не завжди пов’язані з повнотою наукового обгрунтування, а відбуваються частіше на емпіричній основі під впливом ситуативних вимог. Інновації такого роду охоплюють діяльність вчителів-новаторів, вихователів та батьків. У деяких випадках сюди входять i інновації, які здійснені адміністраторами проектувальниками освіти, які працюють у навчально-виховній практиці (художники, музиканти, архітектори, бізнесмени, екологи тощо). Сказане про спонтанний характер інновацій підкреслює необхідність поглибленого аналізу цього виду інновацій з метою виділення позитивних сторін його діяльності.

Другим типом інновацій є інновація в системі освіти, яка є продуктом свідомої, цілеспрямованої та науково культивованої міжпредметної діяльності.

Загальноприйнятої системної класифікації інновацій в освіті досі не створено, хоча багато дослідників намагаються встановити таку класифікацію на основі типології інновацій[331].

Залежно від виду, всі інновації можна поділити на дві групи: матеріальнотехнічні та соціальні. До другої групи належать освітні інновації. Вважається, що соціальні інновації особливо складні для реалізації, оскільки невизначеність їх параметрів i результатів дає змогу моделювати необхідні зміни без їх впровадження. Соціальні інновації більш тісно пов’язані 3 соціальними відносинами, культурою, більш широким охопленням, більшою опорою на особистісні якості новаторів, а переваги не настільки очевидні та доказуємо. Об’єктами змін є самі люди, їхнє становище, статус, звички, стосунки. Інновація створює напругу змін, виявляються стресові ситуації.

Нововведення, інновації, інноваційні процеси мають своїх носіїв. Визначення основних понять інноватики не може бути повним без характеристики людей, які впроваджують інновації. Йдеться про педагогічних новаторів, які вносять конструктивні інновації в педагогічну реальність. Творчі здібності та індивідуальність вчителя не дозволяють автоматично і без змін відтворювати педагогічний досвід. Суб'єктивний фактор відіграє вирішальну роль на етапі впровадження та поширення інновації. На цій фазі освітній новатор 
виступає в ролі носія конкретної інновації і водночас творця чи редактора в процесі впровадження. У більш загальному вигляді новатори можуть набувати таких характеристик. Новатори - це ті, хто хоче запровадити щось нове. Вони можуть виходити як від самої організації (вчителі, шкільні адміністратори) так і ззовні (представники органів управління освітою, дослідники освіти тощо). Вчителів-новаторів відрізняє не лише високий інтелектуальний потенціал, а й критичне ставлення до дійсності, пошук альтернативи іï недосконалості. Як наслідок, такі вчителі часто вступають у конфлікти з оточуючими. У зв’ язку з цим слід працювати з педагогами-новаторами як з окремою соціальною категорією, яка займає особливе місце в освітньому співтоваристві, має свою структуру, психологію та потреби. Без цього розуміння неможливо розвивати інноваційні процеси, поширювати інновації в школах [332].

Учитель, залучений до інноваційних освітніх процесів, повинен володіти високорозвиненою індивідуальною культурою обробки інформації (в тому числі 3 використанням сучасних комп'ютерних технологій), вміти адаптувати іï до здібностей дітей, а також мати дидактичні здібності.

Учитель може реалізувати себе творчо і продуктивно, якщо надати йому можливість грамотно відбирати різні напрямки навчальної діяльності через формування індивідуального пошукового стилю та знаходити адекватні шляхи і засоби реалізації своєї індивідуальності.

Така можливість виникає при різноманітних взаємодіях 3 факторами інноваційного навчального середовища, яке покликане забезпечити як особистісне зростання, так і формування нових психолого-педагогічних утворень. Продуктивна взаємодія зовнішніх обставин і суб'єктивних характеристик педагога забезпечує його творче самовизначення, що встановлює відповідність особистісних вимог професійній діяльності та глибину розуміння змісту освітніх інновацій. На цій основі сам учитель будує суб'єктивно прийнятні моделі навчання та вибору індивідуальних технологій навчання. Рух викладача в особистісному, технічному та професійному сенсі також пов'язаний iз впровадженням інноваційних методів і прийомів[333]. 
Теоретичний аналіз дав можливість припустити, що інноваційні технології можуть бути успішно реалізовані вчителем за таких умов: проблематизація, виявлення протиріч, виявлення та формування особистісних смислів, творча переробка та переосмислення власного та педагогічного досвіду; рефлексія.

Рефлексивна культура як системоутворюючий фактор професіоналізму - це набір навичок, методів і стратегій, які пробуджують стереотипи особистого досвіду та дій шляхом їх переосмислення і тим самим сприяють інноваціям, які ведуть до подолання тих проблемно-конфліктних ситуацій, які виникають під час вирішення професійної справи, завдання.

Дубасенюк О. А., Вознюк О. В. [334] визначають такі умови, які гарантують готовність педагога до розвитку до інноваційної діяльності: свідоме управління професійною діяльністю на основі мотивів і настроїв; проблематизація i суперечливість педагогічної дійсності - бачення зіткнень і невідповідностей, що не спостерігаються безпосередньо; критичне ставлення до педагогічних норм; відображення та побудова смислової системи (смислотворення); відкритість до навколишнього середовища та професійних інновацій; творчо-перетворююче ставлення до світу, що виходить за рамки нормативної зумовленості; прагнення до самореалізації, до втілення своїх намірів і способу життя у професійній діяльності; суб’єктивація елементів в особистісному смисловому змісті, тобто наділення особистісним змістом.

Головна роль інтеграції педагогічних технологій полягає в якісному підвищенні освітнього процесу, що вчиняється на основі спільної педагогічної реалізації всіх уможливлених складників педагогічних технологій.

Таким чином, інноваційні процеси навчання створюють новий вид професійної свідомості та поведінки вчителя, що стає предметом навчальної діяльності. Засобом реалізації інноваційних освітніх процесів у рамках організаційно-педагогічної співпраці школи та університету має стати проектування інноваційного освітнього середовища, що гарантує підвищення ефективності освітніх структур. 